Leucovorin As Adjuvant Treatment in Stage II or III Colon Cancer in the MOSAIC Trial. J Clin Oncol. 2009:27(19):3109-3116.

doi:10.1200/JCO.2008.20.6771

3. Võ Văn Kha. Đánh giá kết quả điều tri hóa chât bổ trợ phác đồ XELOX trong ung thư biểu mô tuyến đai tràng giai đoạn II, III. Luận án Tiến sỹ Y hoc, trường Đai hoc Y Hà Nôi, 2016.

4. Từ Thị Thanh Hương. Đánh giá kết quả hóa tri bổ trơ phác đồ FOLFOX4 trong ung thư biểu mô tuyến đại tràng giai đoan III. Luận án Tiến sỹ Y học, trường Đại học Y Hà Nội, 2019.
5. Tsai Y-J, Lin J-K, Chen W-S, et al. Adjuvant FOLFOX treatment for stage III colon cancer: how many cycles are enough? Springerplus. 2016; 5(1):1318. doi:10.1186/s40064-016-2976-9

6. Nguyê̂n Quang Thái. Nghiên cứu giá trị một số phương pháp çhẩn đoán và kết quả sống 5 năm sau điểu trị phấu thuật ung thư đai tràng. Luận án Tiến sỹ Y hoc, trường Đai hoc Y Hà Nôii, 2002.

7. Phan Thị Hồng Đức. Hóa trị hỗ trợ carcinoma đại tràng giai đoạn III với phác đồ FOLLFOX4. Tạp chí Ung thư học Việt Nam. 2013;4:239-250.

\title{
ĐÁNH GIÁ KẾT QUẢ Xử TRÍ CÁC BIẾN CHỨNG VÀ DI CHỨNG CỦA PHẪU THUÂTT CẮT THANH QUẢN BẢO TỒN TRONG UNG THƯ THANH QUẢN
}

\section{TÓM TẮT}

Mục tiêu nghiên cứu: Xác định tỉ lê và đánh giá kết quả xử trí các biến chứng và di chứng của phâu thuật cắt thanh quản bảo tồn trong ung thư thanh quản. Đối tượng và phương pháp nghiên cứu: nghiên cứu mố tả cắt ngang, 219 bệnh nhân được phâuu thuật cắt thanh quản bảo tồn do ung thư thanh quản, tại bệnh viện tai mũi họng trung ương từ tháng 10/2018 đển 9/2021. Kết quả: Tỷ lệ biến chứng là $17,4 \%$, di chứng là $6,8 \%$. Tỉ lệ biến chứng của từng phương pháp mở sụn giáp cắt dây thanh, cắt thanh quản bán phần ngang trên thanh môn, CHEP, Tucker lần lượt là $20,6 \%, 15,4 \%, 16,4 \%, 17,4 \%$. Tỉ lệ di chứng của từng phương pháp là $0,9 \%, 38,5 \%$, $14,5 \%, 6,8 \%$. Tỉ lê các biến chứng chảy máu $5 \%$, tràn khí 9,5\%, nhiễm trùng vết mổ $2,3 \%$, viêm phổi $4,1 \%$. Di chứng chỉ gặp hep thanh quán với tỉ lệ $6,8 \%$. Kết luận: Phấu thuật cắt thanh quản bảo tồn có tỉ lệ biến chứng và di chứng thấp. Các biến chứng và di chứng có thể xử lý được và đem lại kết quả tốt cho bệnh nhân.

Tư khóa: ung thư thanh quản, cắt thanh quản bảo tồn, biến chứng và di chứng.

\section{SUMMARY}

EVALUATE COMPLICATIONS AND SEQUELAE MANAGEMENT OUTCOME OF CONSERVATION LARYNGEAL SURGERY

Objective: To determinecomplications and sequalae rates postoperative of conservative laryngeal surgery for laryngeal cancer and evaluate results of management outcome. Methods: cross-sectional study of 219 patients underwent conservative laryngeal surgery in National ENT hospital from October 2018 to August 2021. Result: Complication

${ }^{1}$ Bệnh viện Hữu nghi đa khoa Nghệ An

${ }^{2}$ Trường đại họ y Hà Nội

Chịu trách nhiệm chính: Phan Thanh Hưng

Email: phanthanhhung159@gmail.com

Ngày nhận bài: 18.6 .2021

Ngày phản biện khoa học: 18.8.2021

Ngày duyệt bài: 24.8.2021
Phan Thanh Hưng1, Tống Xuân Thắng ${ }^{2}$

rate was $17.4 \%$ and sequela rate was $6,8 \%$, complication rate of cordectomy, supraglottic horizontal, Tuker, CHEP was $20.6 \%, 15.4 \%$, $16.4 \%$, $17.4 \%$ respectively. Sequela rate of cordectomy, supraglottis, Tucker, CHEP was 0,9\%, 38,5\%, 14.5\%, $6.8 \%$ sequentially. Rate of hemmorrhage was $5 \%$ emphysema was $9.5 \%$, wound infection was $2.3 \%$ and pneumomia was $4.1 \%$. Conclusion: the conservative laryngeal surgery has relatively low complication and sequela rates. Postoperative care and management of complication and sequela are important.

Keywords: laryngeal cancer,conservative laryngeal surgery, complication and sequela.

\section{I. ĐẶT VẤN ĐỀ}

Ung thư thanh quản chủ yếu xuất phát từ biểu mô dây thanh, vùng thượng thanh môn ít găp hơn, vùng hạ thanh môn chiếm dưới $1 \%{ }^{1}$. Bệnh liên quan với tình trạng hút thuốc lá và uống nhiều rươu. Điều trị ung thư thanh quản chủ yếu là phẩu thuật và xạ trị, mục tiêu của điều trị không chỉ giải quyết bệnh tích khối u mà còn phải bảo tồn được chức năng của thanh quản. Phẫu thuật hiện nay có hai phương pháp cơ bản là phẫu thuật cắt thanh quản toàn bộ và phẫu thuật bảo tồn thanh quản.

Phẫu thuật cắt thanh quản bảo tồn áp dụng với các tổn thương u còn khu trú giúp bảo vệ chức năng nói, thở theo đường tư nhiên, tránh cho bệnh nhân phải mở khí quản vĩnh viễn. Có nhiều phương pháp phẫu thuật bảo tồn thanh quản khác nhau, tùy theo vị trí khối u và giai đoạn của khối u, tình trạnh của người bệnh và thói quen của phẫu thuật viên, để lựa chọn phương pháp phẫu thuật thích hợp. Ngày nay cùng với sự phát triển của khoa học kỹ thuật, trang thiết bi, phẫu thuât bảo tồn thanh quản đã có nhiều tiến bộ. Tuy nhiên, vẫn không thể tránh khỏi các biến chứng và di chứng mắc phải sau 
phẫu thuật. Nó làm ảnh hưởng nhiều đến kết quả điều trị, tăng chi phí chăm sóc người bệnh, ảnh hưởng đến chất lượng cuộc sống và thậm chí là tính mạng của người bệnh. Chúng tôi tiến hành nghiên cứu này với mục tiêu: Xác định tỉ lệ biến chứng, di chứng của phẫu thuật cắt thanh quản bảo tồn trong ung thư thanh quản và đánh giá kết quả xử trí các biến chứng và di chứng.

\section{II. ĐỐI TƯỢNG VÀ PHƯƠNG PHÁP NGHIÊN CỨU}

2.1 Đối tượng nghiên cứu. 219 bệnh nhân ung thư thanh quản được phẫu thuật cắt thanh quản bảo tồn tại Bệnh viện Tai Mũi Họng TW. Thời gian từ tháng 10/2018 đến tháng 8/2021.

2.1.1.Tiêu chuẩn lựa chọn bệnh nhân.

- Bệnh nhân được phẫu thuật cắt thanh quản bảo tồn bằng các kỹ thuâtt sau: Mở sụn giáp cắt dây thanh; Cắt thanh quản bán phần ngang trên thanh môn; Cắt thanh quản bán phần ngang trên nhẫn tạo hình kiểu CHEP; Cắt thanh quản trán trước tạo hình kiểu Tucker.

- Hồ sơ ghi chép đầy đủ các thông tin (bệnh nhân hồi cứu).

- Bệnh nhân đồng ý tham gia nghiên cứu.

2.1.2. Tiêu chuẩn loại trừ.

- Bệnh nhân ung thư thanh quản được điều trị bằng phẫu thuật cắt thanh quản toàn phần hoặc cắt thanh quản nội soi sử dụng laser.

- Bệnh nhân có di chứng không được theo dõi đầy đủ.

2.2. Thiết kế nghiên cứu : Mô tả cắt ngang

\section{KẾT QUẢ NGHIÊN CỨU}

\section{1. Đăc điểm chung}

- Tuổi trung bình là 61 (21-81).

- Chủ yếu gặp ở nam giới 95,4\%.

- Tỉ lệ hút thuốc lá 81,3\%, uống rượu $61,6 \%$.

- 25,6\% có bệnh kèm theo: cao huyết áp, tim mạch, tiểu đường, COPD...

- Trong 219 bệnh nhân có 48,9\% phẫu thuật mở sụn giáp cắt dây thanh, $5,9 \%$ cắt thanh quản bán phần ngang trên thanh môn, 25,1\% cắt thanh quản bán phần ngang trên nhẫn tạo hình kiểu CHEP, 20,1\% cắt thanh quản trán trước tạo hình kiểu Tucker.

- 52,\% không nạo vét hạch, 28,7\%nạo vét hạch một bên,17,8\% nạo vét hạch hai bên.

3.2. Tỉ lệ biến chứng và di chứng.

3.2.1 Tỉ lệ biến chứng và di chứng.

Bảng 3.1 Tỉ lệ các biến chứng và di chứng $(N=219)$

\begin{tabular}{|c|c|c|c|c|}
\hline \multirow{2}{*}{} & \multicolumn{2}{|c|}{ Có } & \multicolumn{2}{c|}{ Không } \\
\cline { 2 - 5 } & $\mathbf{n}$ & $\mathbf{\%}$ & $\mathbf{n}$ & $\mathbf{\%}$ \\
\hline Biến chứng & 38 & 17,4 & 181 & 82,6 \\
\hline Di chứng & 15 & 6,8 & 202 & 92,2 \\
\hline
\end{tabular}

Trong 219 bệnh nhân nghiên cứu có 38 trường hợp bị biến chứng chiếm $17,4 \%$, và 15 trường hợp có di chứng chiếm $6,8 \%$.

3.2.2.Tỉ lệ biến chứng của các phương pháp phẫu thuật

Bảng 3.2 Tìlệ biến chứng của từng phương pháp phâuu thuật $(N=219)$

\begin{tabular}{|c|c|c|c|c|c|}
\hline Phương pháp & \multicolumn{2}{|c|}{ Có } & \multicolumn{2}{|c|}{ Không } & \multirow{2}{*}{ p } \\
\cline { 2 - 5 } phấu thuật & $\mathbf{n}$ & $\mathbf{\%}$ & $\mathbf{n}$ & $\mathbf{\%}$ & \\
\hline $\begin{array}{c}\text { Mớ sựn giáp cắt } \\
\text { dây thanh }\end{array}$ & 22 & 20,6 & 85 & 79,4 & \\
\hline $\begin{array}{c}\text { Cắt thanh quản ngañ } \\
\text { trên thanh môn }\end{array}$ & 2 & 15,4 & 11 & 84,6 & \\
\hline CHEP & 9 & 16,4 & 46 & 83,6 & 85 \\
\hline Tucker & 5 & 17,4 & 39 & 82,6 & \\
\hline
\end{tabular}

Tỉ lê biến chứng cao nhất ở nhóm bênh nhân được phẫu thuật mở sụn giáp cắt dây thanh $20,6 \%$, tiếp đến lần lượt là ở nhóm phẩu thuật Tucker $16,4 \%$ và CHEP $16,4 \%$ thấp nhất ở nhóm bệnh nhân phẫu thuât cắt thanh quản bán phần ngang trên thanh mổn $15,4 \%$. Sự khác biệt này không có ý nghĩa thống kê với $p=0,585$

\subsubsection{Tỉ lệ di chứng của từng phương} pháp phẫu thuât

Bảng 3.3 Tỉ lệ di chứng của từng phương pháp phẫu thuật ( $N=219$ )

\begin{tabular}{|c|c|c|c|c|c|}
\hline $\begin{array}{c}\text { Phương pháp } \\
\text { phẫu thuật }\end{array}$ & \multicolumn{2}{|c|}{ Có } & \multicolumn{2}{|c|}{ Không } & \multirow{2}{*}{$\mathbf{P}$} \\
\cline { 2 - 5 } & $\mathbf{n}$ & $\mathbf{\%}$ & $\mathbf{n}$ & $\mathbf{\%}$ & \\
\hline $\begin{array}{c}\text { Mở sụn giáp cắt } \\
\text { dây thanh }\end{array}$ & 1 & 0,9 & 106 & 99,1 & \\
\hline $\begin{array}{c}\text { Cắt thanh quản } \\
\text { ngang trên } \\
\text { thanh môn }\end{array}$ & 3 & 23,1 & 10 & 76,9 & \multirow{2}{*}{0.0} \\
\hline CHEP & 8 & 14,5 & 47 & 85,5 & 00 \\
\hline Tucker & 3 & 6,8 & 41 & 93,2 & \\
\hline
\end{tabular}

Tỉ lệ di chứng cao nhất xẩy ra ở nhóm bệnh nhân được phẫu thuật cắt thanh quản ngang trên thanh môn $23,1 \%$. Tiếp theo lần lượt là ở nhóm phẫu thuật CHEP $14,5 \%$ và Tucker $6,8 \%$. Thấp nhất ở nhóm bệnh nhân được phẫu thuật mở sụn giáp cắt dây thanh $0,9 \%$. Sự khác biệt có ý nghĩa thống kê với $p=0.000$

\section{3.Đánh giá kết quả xử trí các biến} chứng và di chứng.

3.3.1. Biến chứng sau phẫu thuật cắt thanh quản bảo tồn

Bảng 3.4 Các loại biến chứng $(N=219)$

\begin{tabular}{|c|c|c|}
\hline Biến chứng & $\mathbf{n}$ & $\mathbf{\%}$ \\
\hline Chảy máu & 11 & $5 \%$ \\
\hline Tràn khí & 21 & $9,5 \%$ \\
\hline Nhiêm trùng & 5 & $2,3 \%$ \\
\hline Viêm phối & 9 & $4,1 \%$ \\
\hline
\end{tabular}

Biến chứng gặp nhiều nhất là tràn khí $9,5 \%$, tiếp theo là chảy máu $5 \%$, viêm phổi $4,1 \%$, tình 
trạng nhiễm trùng gặp ít nhất với 2,3\%

3.3.2. Xử trí chảy máu. Vị trí chảy máu gặp chủ yếu tại chân can nuyn7/11BN $(63,6 \%)$, tại diện cắt u $3 / 11 \mathrm{BN}(27,3 \%)$, vùng nạo vét hạch $1 \mathrm{BN}(9,1 \%)$.

Bảng 3.5 Phương pháp xử trí chảy máu $(N=11)$

\begin{tabular}{|c|c|c|}
\hline Xử trí & $\mathbf{n}$ & $\mathbf{\%}$ \\
\hline Băng ép & 6 & 54,5 \\
\hline Nội soi cầm máu & 3 & 27,3 \\
\hline Mở lại hốc mố cầm máu & 2 & 18,2 \\
\hline
\end{tabular}

Phần lớn bệnh nhân được xử trí bằng cách băng ép $6 / 11$ chiếm $54,5 \%$, Có 2 trường hợp phải mở lại hốc mổ để cầm máu, và 3 trường hợp được tiến hành nội soi cầm máu.

3.3.4. Xử trí tràn khí. Có 21 bênh nhân xuất hiện tràn khí sau mổ, 100\% các bệnh nhân tràn khí dưới da, có 3 bệnh nhân xuất hiện tràn khí trung thấtmức độ nhẹ. Các bệnh nhẩn đều được đều trị bằng cách băng ép, trong đó có 3 bệnh nhân phải tiến hành cắt chỉ vết mổ, không có trường hợp nào phải rạch da, hay đặt dẫn lưu dưới da. Hai bệnh nhân tràn khí trung thất được theo dõi tự phục hồi.

3.3.5.Xử trí nhiễm trùng vết mổ. Trong 5 bệnh nhân bị nhiễm trùng vết mổ, $100 \%$ đều được phối hợp kháng sinh để điều trị, có 3 trường hợp phải cắt chỉ vết mổ và hút sạch mủ, thay băng hàng ngày.

3.3.6. Điều trị viêm phổi. Sau mổ có 9 bệnh nhân bị viêm phổi, không có trường hợp nào bệnh nhân phải điều trị theo kháng sinh đồ, đa số bệnh nhân được phối hợp kháng sinh để điều trị, có $2 / 7$ trường hợp chỉ cần thay kháng sinh.

3.3.7 Xử trí di chứng. Di chứng sau mổ xẩy ra ở 15/219 BN(6,8\%), tất cảđều là các di chứng về đường thở, với các nguyên nhân khác nhau gây hẹp thanh quản.Không gặp các di chứng về đường ăn làm cho bệnh nhân phải đặt sonde ăn, mở thông dạ dày hay cắt thanh quản toàn phần.

Bảng 3.6 Nguyên nhân gây hẹp thanh quản $(N=15)$

\begin{tabular}{|c|c|c|}
\hline Nguyên nhân & $\mathbf{n}$ & $\mathbf{\%}$ \\
\hline Phù nề niêm mạc & 4 & 26,7 \\
\hline Vạt niêm mạc & 4 & 26,7 \\
\hline Tố chức hạt & 3 & 20 \\
\hline Sẹo hẹp & 4 & 26,7 \\
\hline
\end{tabular}

Nguyên nhân gây hẹp thanh quản do phù nề niêm mạc, vạt niêm mạc, sẹo hẹp ở mỗi nhóm là 4/15BN $(26,7 \%)$, do tố chức hạt là $3 / 15$ BN.

Xử trí: 4 bệnh nhân phù nề niêm mac được điều trị nội khoa, 11 bênh nhân do nguyển nhẩn còn lại được điêuu trị bằng phẫu thuật nội soi sử dụng laser để chỉnh hình.

\section{BÀN LUÂN}

4.1 Tỉ lệ biến chứng và di chứng. Các bệnh nhân trong nghiên cứu của chúng tôi được theo dõi sau mổ, tỉ lệ biến chứng $17,4 \%$,các biến chứng chúng tôi gặp là chảy máu, tràn khí, nhiễm trùng vết mổ, viêm phổi, chúng tôi không gặp trường hợp nào rò ống họng sau mổ, và cũng không gặp trường hợp nào bị rò bạch huyết. Trong nghiên cứu của Ian Ganly ${ }^{2}$ tiến hành trên 150 bệnh nhân năm 2009, tỉ lệ biến chứng chung $20 \%$, biến chứng tại chỗ $11 \%$, rò ống họng $4 \%$, rò bạch huyết $1 \%$. Có sự khác biệt trển là do trong số bệnh nhân của Ganly có 21 bệnh nhân phẫu thuật cứu trợ sauxạ trị thất bại.

Tî lệ biến chứng theo từng phương pháp phẫu thuật mở sụn giáp cắt dây thanh, cắt thanh quản ngang trên thanh môn, cắt thanh quản ngang trên nhẫn có tạo hình kiểu $\mathrm{CHEP}$, cắt thanh quản kiểu Tucker lần lượt là 20,6\%, $15,4 \%, 16,4 \%, 17,4 \%$. Trong nghiên cứu của Tông Xuân Thắng ${ }^{3}$ tiến hành trên bênh nhân cắt thanh quản tạo hình kiểu CHEP tỉ lệ biến chứng là $7,8 \%$ thấp hơn so với nghiên cứu của chúng tôi là do tác giả chỉ tập trung vào các biến chứng chảy máu, nhiễm trùng và rò, không đề cập đến biến chứng tràn khí và viêm phổi.Trong nghiên cứu của Lê Minh Kỳ ${ }^{4}$ tiến hành trên 17 bệnh nhân cắt thanh quản Tucker có ghi nhận một trường hợp chảy máu sau mổ.

Các bệnh nhân sau phẫu thuật bảo tồn thanh quản sẽ được tiến hành thay canyl shiley để tập nói,bắt đầu sớm các bài tập phục hồi chức năng về nuốt và nói. Nhờ đó tránh cho bệnh nhân tình trạng cứng khớp nhẫn phễu, và hình thành sẹo hẹp. Trong nghiên cứu của chúng tôi có $6,8 \%$ di chứng sau phẫu thuật, tất cả các di chứng là do hẹp thanh quản. Chúng tôi không ghi nhân các di chứng rối loạn nuốt khiến bệnh nhân phải đặt sonde ăn kéo dài, hay mở thông dạ dày.

Tî lệ di chứng cao nhất xẩy ra ở nhóm bệnh nhân được phẫu thuật cắt thanh quản ngang trên thanh môn $23,1 \%$. Tiếp theo lần lượt là ở nhóm phẫu thuật CHEP $14,5 \%$ và Tucker $6,8 \%$. Thấp nhất ở nhóm bệnh nhân được phẫu thuật mở sụn giáp cắt dây thanh $0,9 \%$. Sự khác biệt có ý nghĩa thống kê với $p=0.000$. Các bệnh nhân được phẫu thuật cắt thanh quản bán phần ngang trên thanh môn được áp dụng cho các bệnh nhân có khối u ở vùng thượng thanh môn, do đó nguy cơ di căn hạch sớm, nên các bệnh nhân sau mổ thường phải điều trị bổ trợ bằng xạ trị hoặc hóa xạ trị đồng thời, làm tăng nguy cơ phù nề niêm mạc, hình thành vạt niêm mạc và sẹo hẹp. 
4.3 Đánh giá kết quả xử trí các biến chứng và di chứng. Chảy máu sau phẫu thuật trong nghiên cứu của chúng tôi tất cả ở mức độ nhe, không làm rối loạn huyết động, không có bệnh nhân nào phải truyền máu. Vị trí chảy máu gặp chủ yếu tại chân can nuyn63,6\%, do cầm máu không kỹ và sự di chuyển của can nuyn làm tổn thương các mạch máu, các trường hợp này đều được xử trí tại buồng bệnh bằng cách băng ép tại chỗ, có một bệnh nhân không cầm máu phải vào nhà mổ để tìm điểm chảy và cầm máu bằng đông điện. Có 3 bệnh nhân chảy máu tại diện cắt $u$ được nội soi đốt điểm chảy tại nhà mổ. Một bệnh nhân chảy máu do nạo vét hạch cổ, khi mở lại hốc mổ thấy chảy máu từ nhánh của tĩnh mạch cảnh trong đã được buốc chỉ lại. Sau phẫu thuật tất cả bệnh nhân đều có kết quả tốt, không có trường hợp nào tái phát chảy máu lại.

Biến chứng tràn khí găp nhiêu nhất trong nghiên cứu của chúng tôi với tỉ lệ9, $5 \%$, tỉ lệ cao là do các bệnh nhân hầu hết được phẫu thuật mở khí quản, và mở sụn giáp hoặc cắt bỏ một phần sụn giáp. Tất cả các bệnh nhẩn đều có tràn khí dưới da, có 3 bệnh nhân xuất hiện tràn khí trung thất mức độ nhẹ. Các bệnh nhân đều xuất hiện tràn khí sau mổ một ngày có 3 bệnh nhân tràn khí sau khi rút can nuyn, do sau mổ bênh nhân thường xuất ho nhiều. Các bệnh nhân được điều trị bằng cách ép, nghỉ ngơi tại giường bệnh, giảm ho, có 3 bênh nhân xuất hiên tràn khí sau khi rút can nuyn và khâu lỗ mở khí quản nên đã được cắt chỉ và băng ép vùng cổ. Ba bệnh nhân tràn khí trung thất mức độ nhẹ không tăng lên, được hỗ trợ thở oxy, tình trạng tràn khí tự hết. Tất cả các bệnh nhân đều hết tràn khí sau 1 tuần. Không có trường hợp nào phải rạch da, đặt dẫn lưu dưới da hay dẫn lưu màng phổi khác với nghiên cứu của Manouchehr Aghajanzadeh ${ }^{5}$ tất cả các bệnh nhân đều được rạch da ở dưới xương đòn $2 \mathrm{~cm}$ và đặt dẫn lưu dưới da. Có sự khác biệt này là do mức độ tràn khí ở các bệnh nhân của chúng tôi đều nhẹ.

Các bênh nhân bị nhiễm khuẩn hốc mổ được điều trị bằng kháng sinh phối hợp, phổ rộng, kết hợp với kháng sinh chống ky. khí. Trong đó có 3 trường hợp phải cắt chỉ vết mổ, hút sạch mủ và thay băng hàng ngày. Tất cả các bệnh nhân đều đáp ứng tốt sau một tuần điều trị.Đề giảm ngự cơ nhiểm khuẩn hốc mổ trong quá trình phẫu thuât cần bộc lộ phẫu trường tối ưu nhất, hạ chế tổn thương các mô không cần thiết, cầm máu kỹ hốc mổ, đảm bảo trường mổ luôn được giữa ẩm, trước khi đóng hốc mổ cần cầm máu kỹ, rửa sạch phẫu trường. Chăm sóc sau mổ phải đảm bảo vô khuẩn, kiểm tra dẫn lưu kỹ không để hở, tắc, tụt dẫn lưu.

Sau phẫu thuật có 9 bệnh nhân xuất hiên viêm phổi, chiếm $4,1 \%$. Trong nghiên cứu của Oreste Gallo ${ }^{6}$ trên 535 bênh nhân từ 1982 đến 2007 tỉ lệ viêm phổi là 13,3\%. Do trong nghiên cứu của chúng tôi có tiến hành trên nhóm bệnh nhân mở sụn giáp cắt dây thanh. Ngoài ra thì sự phát triển của kỹ thuật phẫu thuật, chăm sóc hậu phẫu và kháng sinh đã làm giảm viêm phổi bệnh viện. Các bệnh nhân viêm phổi phần lớn là do nuốt sặc sau phẫu thuât, ngoài ra do phải thở qua can nuyn cũng làm tăng nguy cơ viêm phổi. Trong 9 bệnh nhân viêm phổi có 2 bệnh nhân thay kháng sinh, 7 bệnh nhân phải phối hợp kháng sinh, tất cả các bệnh nhân đều đáp ứng tốt, sau 3 ngày điêu trị thì hết sốt, giảm ho khạc đờm và ổn định sau 10 ngày.

Di chứng đường thở gặp ở 15 bệnh nhân $(6,8 \%)$, tỉ lệ này thấp hơn so với nghiên cứu của Marco Lucioni ${ }^{7}$, khi tiến hành trên các bênh nhân cắt thanh quản bán phần ngang type II và type IIItỉ lệ hẹp thanh quản là $15,4 \%$. Trong nhóm nghiên cứu của chúng tôi phần lớn bệnh nhân được phẫu thuât mở sun giáp cắt dầy thanh. Nguyên nhân gây nên hẹp thanh quản là do phù nề xuất hiện sau xạ trị, vạt niêm mạc, tổ chức hat và seo hep. Trong đó thì có 4 bệnh nhân bi phù nề niêm mac nguyên nhân do xạ trị sau mổ được điêu trị nội khoa, còn lại 11 bệnh nhân được điều trị bằng phẫu thuật nội soi chỉnh hình bằng laser. Kết quả điều trị 14 bệnh nhân đã rút được can nuyn, còn một bệnh nhân hiên tại đang mang can nuyn tháng thứ 8 và hiện tại chúng tôi chưa ghi nhân trường hợp nào tái hẹp sau mô.

\section{KẾT LUÂNN}

Tỉ lệ biến chứng chung là 17,4\%, di chứng là $6.8 \%$. Các phương pháp phẫu thuật mở sụn giáp cắt dây thanh, cắt thanh quản bán phần ngang trên thành môn, cắt thanh quản bán phần ngang trên nhẫn tạo hình kiểu CHEP, cắt thanh quản bán phần tạo hình kiểu Tucker có tỉ lệ biến chứng lần lượt là $20.6 \%, 15.4 \%, 16.4 \%, 17.4 \%$, tỉ lệ di chứng tương ứng là $0,9 \%, 38,5 \%, 14.5 \%$, $6.8 \%$. Di chứng chúng tôi gặp trong tất cả các trường hợp là do hẹp thanh quản.

Các biến chứng và di chứng sau phẫu thuật được phát hiện sớm và xử trí tốt.

\section{TÀI LIỆU THAM KHẢO}

1. Chu EA, Kim YJ. Laryngeal cancer: diagnosis and preoperative work-up. Otolaryngol Clin North Am. 2008;41(4):673-695, v. doi:10.1016/ 
j.otc.2008.01.016

2. Ganly I, Patel SG, Matsuo J, et al. Analysis of postoperative complications of open partial laryngectomy. Head Neck. 2009;31(3):338-345. doi:10.1002/hed.20975

3. Tống Xuân Thắng. Các biến chứng và di chứng sau cắt một phần thanh quản trên nhẫn có tạo hình kiểu nhẫn - móng - thanh thiêtt. Tap chí Tai Mũi Họng Việt Nam. 2013;58-13:33-38.

4. Lê Minh Kỳ. Nghiên cứu ứng dung phẫu thuât cắt bán phần thanh quản Tucker trong điêu trị ung thư thanh quản. Tạp Chí Học Việt Nam. 2012;tâp 392:43-46.

5. Aghajanzadeh M, Dehnadi A, Ebrahimi $\mathbf{H}$, et al. Classification and Management of
Subcutaneous Emphysema: a 10-Year Experience. Indian J Surg. 2015;77(S2):673-677. doi:10.1007/s12262-013-0975-4

6. Gallo 0 , Locatello LG, Larotonda G, Napoleone V, Cannavicci A. Nomograms for prediction of postoperative complications in open partial laryngeal surgery: GALLO ET AL.J Surg Oncol.

2018;118(6):1050-1057. doi:10.1002/jso.25232

7. Lucioni $M$, Bertolin A, Lionello $M$, et al. Transoral laser microsurgery for managing laryngeal stenosis after reconstructive partial laryngectomies: TLM for Postoperative Laryngeal Stenosis. The Laryngoscope. 2017;127(2):359365. doi:10.1002/lary.26056

\title{
ĐÁNH GIÁ HIÊU QUẢ IN VITRO CỦA CÁC PHỐI HỢP KHÁNG SINH TRÊN PHẾ CẦU GÂY VIÊM PHỔI CộNG ĐÔNG Ở TRẺ EM
}

\author{
Nguyễn Thị Nam Phong*, Phạm Viết Tín*, \\ Võ Đình Sơn*, Trần Thị Thúy Nga*, Đỗ Thị Hồng Tươ***
}

\section{TÓM TẮT}

Đặt vấn đề: Kháng sinh và các phác đồ phối hợp là các liệu pháp chính trong điều trị viêm phổi cộng đồng (VPCĐ). Trước những thách thức gia tăng nhanh chóng các chủng vi khuẩn phế cầu (PC) đa đề kháng tại Việt Nam, cần thiết phải đánh giá lại hiêu quả của các phối hợp kháng sinh nhằm hồ trợ kiếm soát đề kháng kháng sinh và lựa chọn liệu pháp điêu trị phù hơp. Mục tiêu nghiên cứu: Khảo sát sự hiêp đồng tác dụng của một số phối hợp kháng sinh đang được sử dụng trong điêu tri VPCĐ ở trẻ em trên các chủng phế cầu đa kháng. Phương pháp nghiên cứu: Nghiên cứu thực nghiêm đánh giá hiệu quả hiêp lực tác động của một sổ cặp phối hợp kháng sinh trên phế cầu đa kháng bằng phương pháp E-Test. Kết quả: Sự hiện diện của azithromycin, gentamicin làm giảm MIC của các kháng sinh sử dung trong phối hợp với cefotaxim, ceftriaxon trên chủng PC. Các kháng sinh trong các cặp phối hợp (gentamycin + cefotaxim) và (gentamicin + ceftriaxon) làm tăng tác dụng hồ trợ lần nhau trên chủng PCa, tuy nhiên chưa có tác dụng hiệp lực rõ ràng. Các cặp phối hợp macrolid và beta-lactam chưa thể hiện được tác dụng hiệp đồng diệt khuẩn in vitro. Kết luận: Trong trường hợp VPCĐ do phế cầu đa kháng thuốc, các phối hợp giửa nhóm macrolid và beta-lactam không đem lại hiệu quả hiêp lực tác động in vitro so với kháng sinh riêng lẻ. Các bác sĩ lâm sàng có thể cân nhắc lựa chọn các cặp kháng sinh phù hợp để nâng cao hiệu quả điều trị.

Tư khóa: Phối hợp kháng sinh, in vitro, E-test, viêm phổi cộng đồng, phế cầu khuẩn

\footnotetext{
*Trường Đại học Kỹ thuâat Y-Dược Đà Nã̃ng

**Dai hoc Y Dước Thành phố Hî̀ Chí Minh

Chịu trách nhiệm chính: Đố Thị Hồng Tươi

Email: hongtuoi@ump.edu.vn

Ngày nhận bài: 22.6.2021

Ngày phản biên khoa hoc: 19.8.2021

Ngày duyệt bài: 25.8.2021
}

\section{SUMMARY}

IN-VITRO EFFICACY EVALUATION OF ANTIMICROBIAL COMBINATION ON PNEUMOCOCCAL-INFECTED- COMMUNITYACQUIRED PNEUMONIA IN CHILDREN

Introduction: Antibiotics and combination regimens are of importance in the treatment of Community-Acquired Pneumonia (CAP). In the face of the rapid emergence of multidrug-resistant pneumococcal strains, it is necessary to re-evaluate the efficacy of combination therapies to support controlling antimicrobial resistance and selecting appropriate regimens for the treatment of CAP. Objectives: To investigate the synergistic effect of some commonly used combination therapy for the treatment of CAP on multidrug-resistant pneumococcal isolates. Methods: The experimental study was conducted to evaluate the synergistic effects of several dual antimicrobial therapies on multidrugresistant pneumococcal isolates using E-test methods. Results: The presence of azithromycin, gentamicin reduced the MIC of antibiotics used in combination with cefotaxime, ceftriaxone on the pneumococcal strains. Gentamicin-plus-cefotaxime and gentamicinplus-ceftriaxone combinations showed the additive antimicrobial effects on the pneumococcal strain Pca; however, there were no clear synergistic activities. Macrolide and beta-lactam combinations have not shown in vitro synergistic bactericidal effects. Conclusions: In the case of CAP induced by multidrug-resistant Streptococcus pneumoniae, combining macrolides and $\beta$-lactams does not produce in vitro synergistic effects. The clinicians should carefully consider the selection of appropriate antibiotic combinations to enhance the treatment efficacy.

Keywords: Combination therapy, in vitro, E-test, Community-Acquired Pneumonia, Streptococcus pneumoniae 